\title{
Identification and mapping of recent rainfall-induced landslides using elevation data collected by airborne Lidar
}

\author{
F. Ardizzone, M. Cardinali, M. Galli, F. Guzzetti, and P. Reichenbach \\ CNR IRPI, via della Madonna Alta 126, 06128 Perugia, Italy \\ Received: 1 August 2007 - Revised: 28 September 2007 - Accepted: 5 October 2007 - Published: 6 November 2007
}

\begin{abstract}
A high resolution Digital Elevation Model with a ground resolution of $2 \mathrm{~m} \times 2 \mathrm{~m}\left(\mathrm{DEM}_{2}\right)$ was obtained for the Collazzone area, central Umbria, through weighted linear interpolation of elevation points acquired by Airborne Lidar Swath Mapping. Acquisition of the elevation data was performed on 3 May 2004, following a rainfall period that resulted in numerous landslides. A reconnaissance field survey conducted immediately after the rainfall period allowed mapping 70 landslides in the study area, for a total landslide area of $2.7 \times 10^{5} \mathrm{~m}^{2}$. Topographic derivative maps obtained from the $\mathrm{DEM}_{2}$ were used to update the reconnaissance landslide inventory map in 22 selected sub-areas. The revised inventory map shows $27 \%$ more landslides and 39\% less total landslide area, corresponding to a smaller average landslide size. Discrepancies between the reconnaissance and the revised inventory maps were attributed to mapping errors and imprecision chiefly in the reconnaissance field inventory. Landslides identified exploiting the Lidar elevation data matched the local topography more accurately than the same landslides mapped using the existing topographic maps. Reasons for the difference include an incomplete or inaccurate view of the landslides in the field, an unfaithful representation of topography in the based maps, and the limited time available to map the landslides in the field. The high resolution $\mathrm{DEM}_{2}$ was compared to a coarser resolution $(10 \mathrm{~m} \times 10 \mathrm{~m}) \mathrm{DEM}_{10}$ to establish how well the two DEMs captured the topographic signature of landslides. Results indicate that the improved topographic information provided by $\mathrm{DEM}_{2}$ was significant in identifying recent rainfallinduced landslides, and was less significant in improving the representation of stable slopes.
\end{abstract}

Correspondence to: F. Ardizzone

(francesca.ardizzone@irpi.cnr.it)

\section{Introduction}

Landslides can be identified and mapped using a variety of techniques (Guzzetti et al., 2000), including: (i) geomorphological field mapping (Brunsden, 1985; 1993), (ii) interpretation of vertical or oblique stereoscopic aerial photographs ("air photo interpretation", API) (Rib and Liang, 1978; Turner and Schuster, 1996), (iii) surface and subsurface monitoring (Petley, 1984; Franklin, 1984), and (iv) innovative remote sensing technologies (Mantovani et al., 1996; IGOS Geohazards, 2003; Singhroy, 2005) such as the analysis of synthetic aperture radar (SAR) images (e.g., Czuchlewski et al., 2003; Hilley et al., 2004; Singhroy and Molck, 2004; Catani et al., 2005; CENR/IWGEO, 2005; Singhroy, 2005), the interpretation of high resolution multispectral images (Zinck et al., 2001; Cheng et al., 2004), and the analysis of Digital Elevation Models (DEMs) obtained from space or airborne sensors (Kääb, 2002; McKean and Roering, 2003; Schulz, 2004, 2005; Catani et al., 2005). Historical analysis of archives, chronicles, and newspapers has also been used to compile landslide catalogues and to prepare landslide maps (e.g., Reichenbach et al., 1998; Salvati et al., 2003, 2006).

A landslide inventory map is the simplest form of landslide map (Pašek, 1975; Hansen, 1984; Wieczorek, 1984; Guzzetti et al., 2000). A landslide event inventory map is a particular type of landslide map that shows the effects of a single landslide trigger, such as an earthquake (Harp and Jibson, 1996), a rainfall event (Bucknam et al., 2001; Guzzetti et al., 2004; Cardinali et al., 2006), or a rapid snowmelt event (Cardinali et al., 2001). Good quality event inventory maps are statistically complete, and provide unique information on the statistics of landslide areas (Guzzetti et al., 2002; Malamud et al., 2004). Different techniques can be used to compile landslide event inventory maps, including: detailed or reconnaissance field surveys, interpretation of aerial photographs taken shortly after the event, and systematic analysis of media

Published by Copernicus Publications on behalf of the European Geosciences Union. 

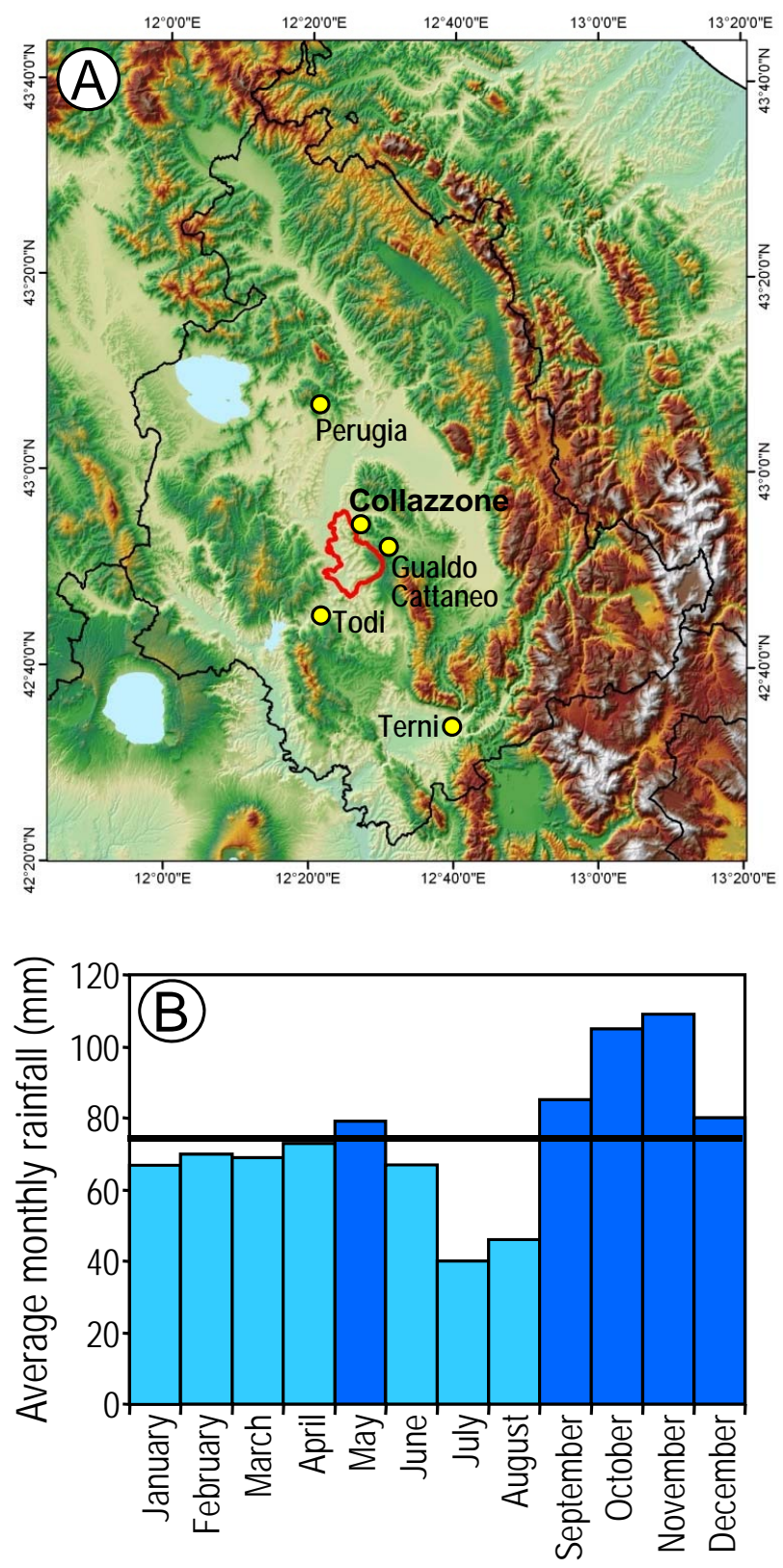

Fig. 1. (A) Map portraying terrain morphology in Umbria, central Italy, and location of the Collazzone study area, shown by red line. (B) Average monthly rainfall for Collazzone area. Rainfall data for the Casalina rain gauge cover the 80-year period from 1921 to 2001. Thick black line shows monthly average. Light blue bars show months below average, and dark blue bars show months above average.

reports (e.g., newspaper articles, radio and television programs, etc.). A combination of these techniques is often used.

Regardless of the adopted technique, preparing a landslide event inventory map is a difficult and time-consuming task. In this work, we report on an experiment aimed at exploiting high resolution elevation data obtained by an Airborne Laser Scanner (ALS) to identify and map recent rainfall-induced landslides in Umbria, Central Italy.

\section{Lidar technology}

There are many methods that can be used to collect elevation data, including conventional ground surveys, digital photogrammetry, remote sensing, and Lidar (Ackermann, 1999; Kovalev and Eichinger, 2004; Lillesand et al., 2004). Lidar is an active sensory system that uses laser light to measure distances. When mounted in an airborne platform, this device can rapidly measure distances between the sensor on the airborne platform and points on the ground to collect and generate densely spaced and highly accurate elevation data. The use of Lidar technology for accurate determination of terrain elevation began in the late 1970s (Ackermann, 1999; Lillesand et al., 2004). Modern Lidar acquisition has typically an aircraft equipped with single or multiple airborne ground positioning systems (GPS), an inertial measuring unit (IMU), a rapidly pulsing laser (from 20000 to 50000 pulses/s), and an adequate computer support. The Lidar system requires a surveyed ground base location to establish the accuracy of the Lidar data (Lillesand et al., 2004). Modern Lidar technology is well suited for the generation of high resolution Digital Elevation Models (DEM) (Ackermann, 1999; Kovalev and Eichinger, 2004; Lillesand et al., 2004).

\section{Study area}

The study area extends for about $90 \mathrm{~km}^{2}$ in central Umbria, Italy, in the municipalities of Collazzone, Todi and Gualdo Cattaneo (Fig. 1a). In the area, elevation ranges from $145 \mathrm{~m}$ along the Tiber River flood plain to $634 \mathrm{~m}$ at Monte di Grutti. Terrain gradient computed from a $10 \mathrm{~m} \times 10 \mathrm{~m}$ DEM ranges from $0^{\circ}$ to $63.7^{\circ}$ degree, with a mean value of $9.9^{\circ}$ and a standard deviation of $6.4^{\circ}$. Landscape is hilly, and lithology and the attitude of bedding planes control the morphology of the slopes. Sedimentary rocks crop out in the area, including (i) fluvial deposits, (ii) continental gravel, sand and clay, (iii) travertine, (iv) layered sandstone and marl in various percentages, and (v) thinly layered limestone (Conti et al., 1977; Servizio Geologico Nazionale, 1980; Cencetti, 1990; Barchi et al., 1991). Climate is Mediterranean, annual rainfall averages $884 \mathrm{~mm}$, and precipitation is most abundant in the period from September to December (Fig. 1b). Snow falls more or less every year, but reaches a depth greater than a few centimetres only about every five years. Rainfall and snowmelt-induced landslides are abundant in the area, and range in type and volume from large translational slides to deep and shallow flows (Guzzetti et al., 2006a; Galli et al., 2007) (Fig. 2). 

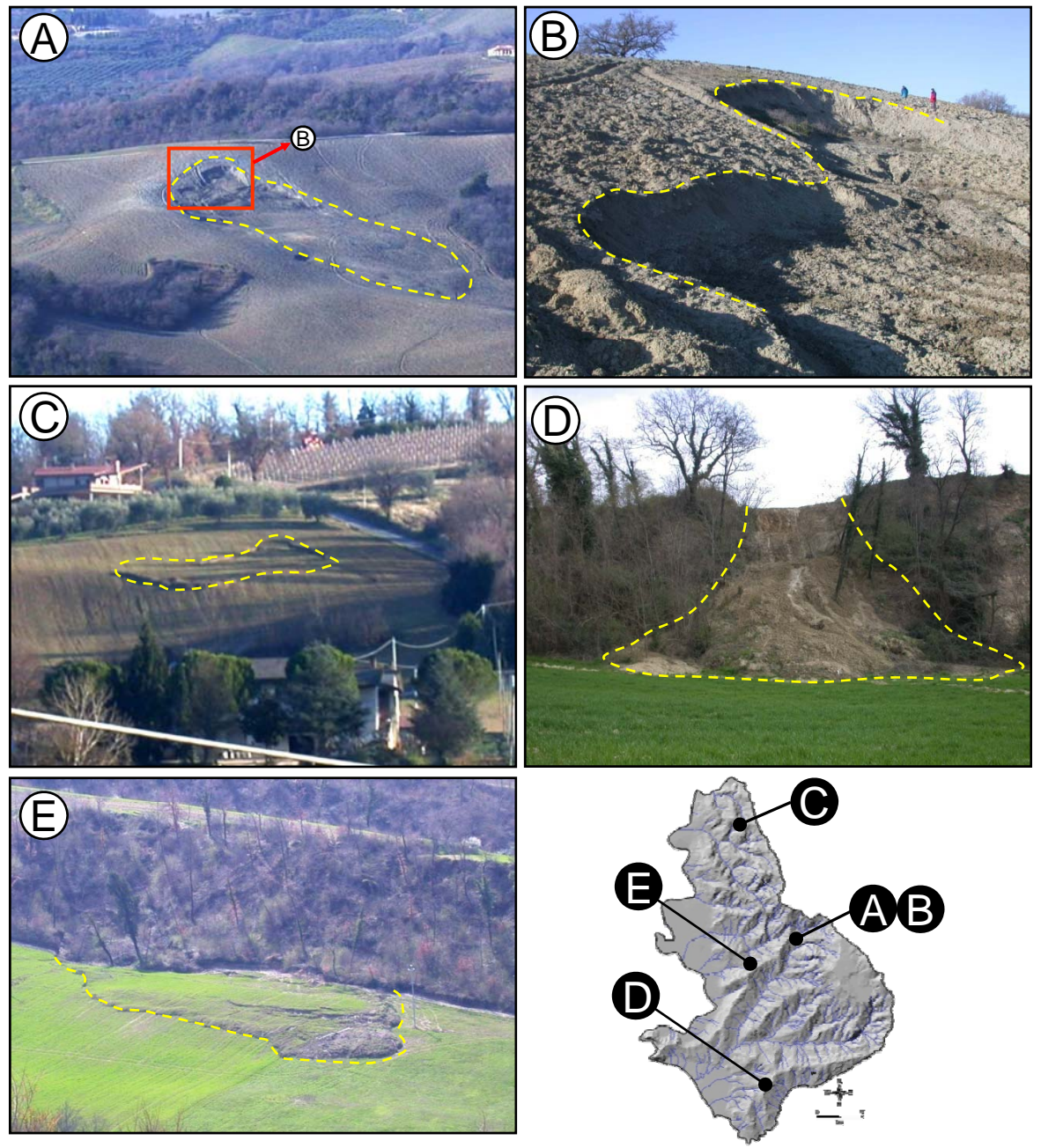

Fig. 2. Typical landslides in the Collazzone area. Yellow dashed lines show landslide boundary. (A) Translational slide. Red box shows location of (B). (B) Detail of the scarp area of the translational slide shown in (A). (C) Shallow soil slide. (D) Shallow disrupted slide. (E) Compound slide - earth flow.

\section{Available data}

For the study area, landslide and topographic information was available in digital format, including: (i) a multitemporal landslide inventory map, at 1:10000 scale, (ii) a reconnaissance landslide event inventory map showing landslides triggered by rainfall in April 2004, (iii) a medium resolution $(10 \mathrm{~m} \times 10 \mathrm{~m})$ Digital Elevation Model $\left(\mathrm{DEM}_{10}\right)$, and (iv) a high resolution $(2 \mathrm{~m} \times 2 \mathrm{~m})$ Digital Elevation Model $\left(\mathrm{DEM}_{2}\right)$.

\subsection{Multi-temporal landslide inventory}

A multi-temporal landslide inventory map was available for the Collazzone study area. The map was prepared at 1:10 000 scale through the systematic interpretation of five sets of aerial photographs flown in the period from 1941 to 1997, and geomorphological field mapping conducted from 1998 to 2003 following periods of prolonged rainfall (Guzzetti et al., 2006a; Galli et al., 2007).

The multi-temporal inventory map shows 2564 landslides (Fig. 3), for a total landslide area of $22.1 \mathrm{~km}^{2}$, corresponding to a landslide density of 32.5 slope failures per square kilometre in the hilly portion of the study area. Due to geographical overlap of landslides of different periods, the total area affected by landslides is $16.5 \mathrm{~km}^{2}, 20.9 \%$ of the hilly portion of the study area. The total area affected by landslides is the area of slope surface disturbed by landslides, including the crown, transport, and depositional areas. Mapped landslides extend in size from $78 \mathrm{~m}^{2}$ to $1.45 \times 10^{6} \mathrm{~m}^{2}$ (mean= $8634 \mathrm{~m}^{2}$, median $=2741 \mathrm{~m}^{2}$, std. dev. $=36181 \mathrm{~m}^{2}$ ). The most abundant failures shown in the map have an area of about $815 \mathrm{~m}^{2}$. 


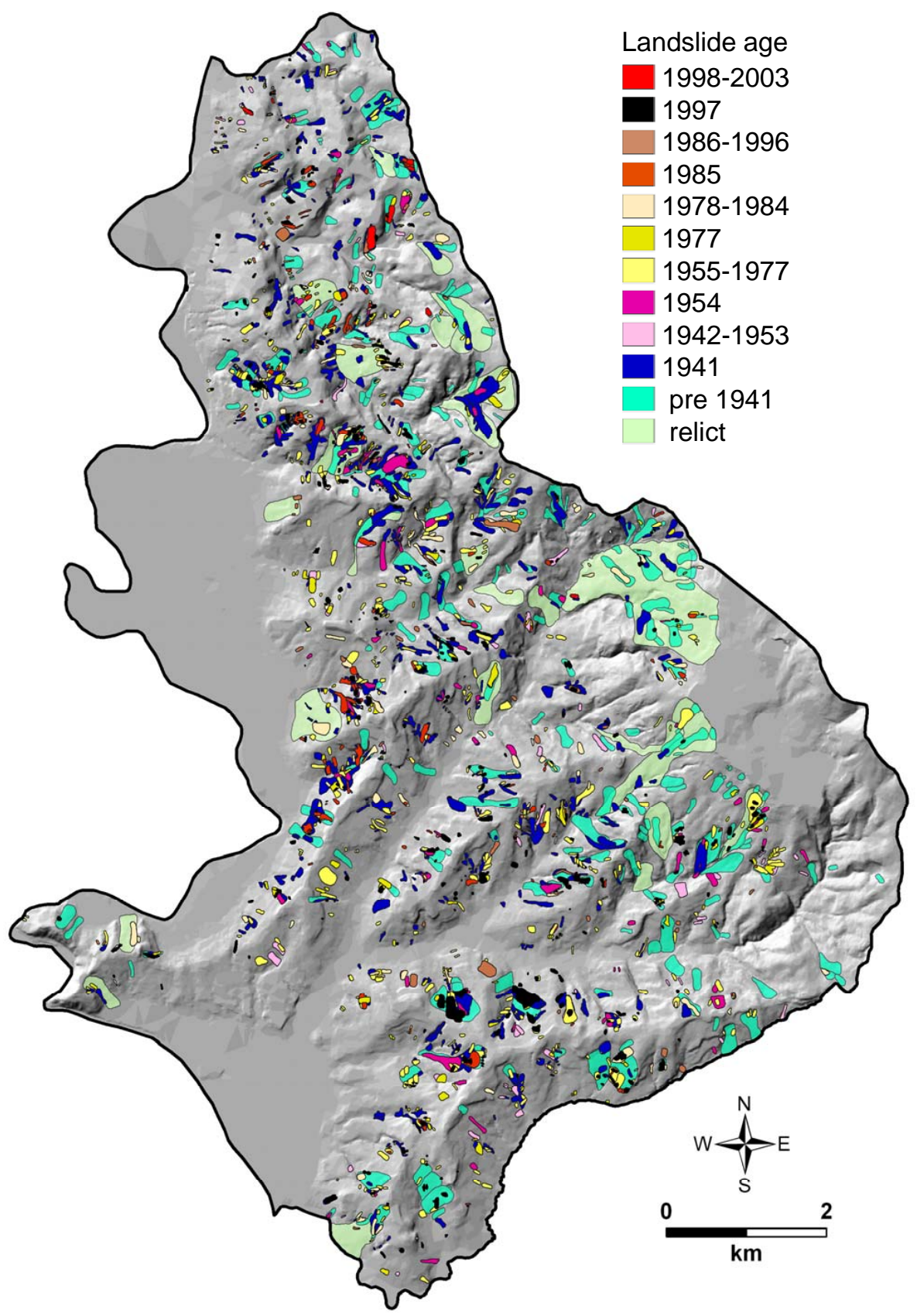

Fig. 3. Multi-temporal inventory map for the Collazzone area (Guzzetti et al., 2006a; Galli et al., 2007). Shaded relief image of the study area obtained from a medium-resolution $(10 \mathrm{~m} \times 10 \mathrm{~m})$ Digital Elevation Model $\left(\mathrm{DEM}_{10}\right)$.

\subsection{Landslide event inventory}

The period from December to April 2004 was wet in Umbria and rainfall-induced landslides occurred at several sites, including the Collazzone area. To map recent rainfall-induced landslides in the Collazzone area, four geomorphologists conducted a reconnaissance field survey driving and walking systematically along main, secondary, and farm roads present in the study area. Geomorphologists stopped where single or multiple landslides were identified, and at viewing points to check individual and multiple slopes. In the field, single and pseudo-stereoscopic photographs of each landslide or group of landslides were taken. The photographs were used to locate the landslides on the topographic maps, to help characterize the type and the size of the mass movements, and to determine the local terrain gradient. Landslides identified in the field and in the photographs were mapped at 1:10 000 scale using topographic base maps (CTR) published 
in 1999 (Fig. 4). The recent landslides were mostly shallow and with fewer deep-seated failures (Fig. 5). Shallow failures were classified as soil slides (62 failures) or compound slide - earth flows (3 failures). Deep-seated failures (5 failures) were translational slide or complex mass movements. Most of the recent rainfall-induced landslides occurred in cultivated or barren areas. No landslide was identified in forested terrain.

The resulting reconnaissance landslide event inventory map (Fig. 4) shows 70 landslides ranging in size from $97 \mathrm{~m}^{2}$ to about $3.2 \times 10^{4} \mathrm{~m}^{2}\left(\right.$ mean $=3812 \mathrm{~m}^{2}$, median $=1443 \mathrm{~m}^{2}$, std. dev. $=5277 \mathrm{~m}^{2}$ ), for a total landslide area of $2.7 \times 10^{5} \mathrm{~m}^{2}$, $0.34 \%$ of the hilly portion of the study area. The most abundant failures shown in the event inventory map have an area of about $1500 \mathrm{~m}^{2}$.

\subsection{Medium resolution Digital Elevation Model}

For the study area, a medium resolution DEM with a ground resolution of $10 \mathrm{~m} \times 10 \mathrm{~m}$ was available $\left(\mathrm{DEM}_{10}\right)$ (Fig. 3). The $\mathrm{DEM}_{10}$ was prepared by automatic interpolation of 10- and 5-m interval contour lines obtained from the same 1:10000 scale topographic maps used to map the landslides. First, Intergraph ${ }^{\circledR}$ Terrain Analyst ${ }^{\mathrm{TM}}$ version 7.01 was used to build a Triangulated Irregular Network (TIN) of elevation values from the contour lines. In the process, automatic break lines generation was used to infer relevant morphological features. Next, terrain elevation at grid nodes spaced $10 \mathrm{~m} \times 10 \mathrm{~m}$ on the ground was determined through weighted linear interpolation.

\subsection{High resolution Digital Elevation Model}

On 3 May 2004, a Dornier 228-110 aircraft operated by the Airborne Research and Survey Facility (ARSF) of the UK National Environment Research Council (NERC) flew an Optech Airborne Laser Terrain Mapper (ALTM) 3033 (Fig. 6) over the Collazzone area, and performed an Airborne Lidar Swath Mapping (ALSM). The high-accuracy laser rangefinder collected an average of 33000 laser observations per second from an average flying height of about $2800 \mathrm{~m}$, corresponding to an average distance to the ground of 2200 to $2650 \mathrm{~m}$. First pulse, last pulse and intensity data were recorded. To guarantee the correct data localization, two GPS stations were installed in the study area with an acquisition time of one second. The Lidar data were processed by the Unit of Landscape Modelling of Cambridge University. GPS post-processing was performed using Applanix PosPac version 3.02 software, and laser data post-processing was performed using Optech's REALM version $3.03 \mathrm{~d}$ software. No correction was performed to remove the effect of the forest cover, or side-lap effects between adjacent Lidar acquisition strips. The result was a cloud of 55.7 million elevation points covering an area of about $230 \mathrm{~km}^{2}$ encompassing the Collazzone study area. In the study area, about

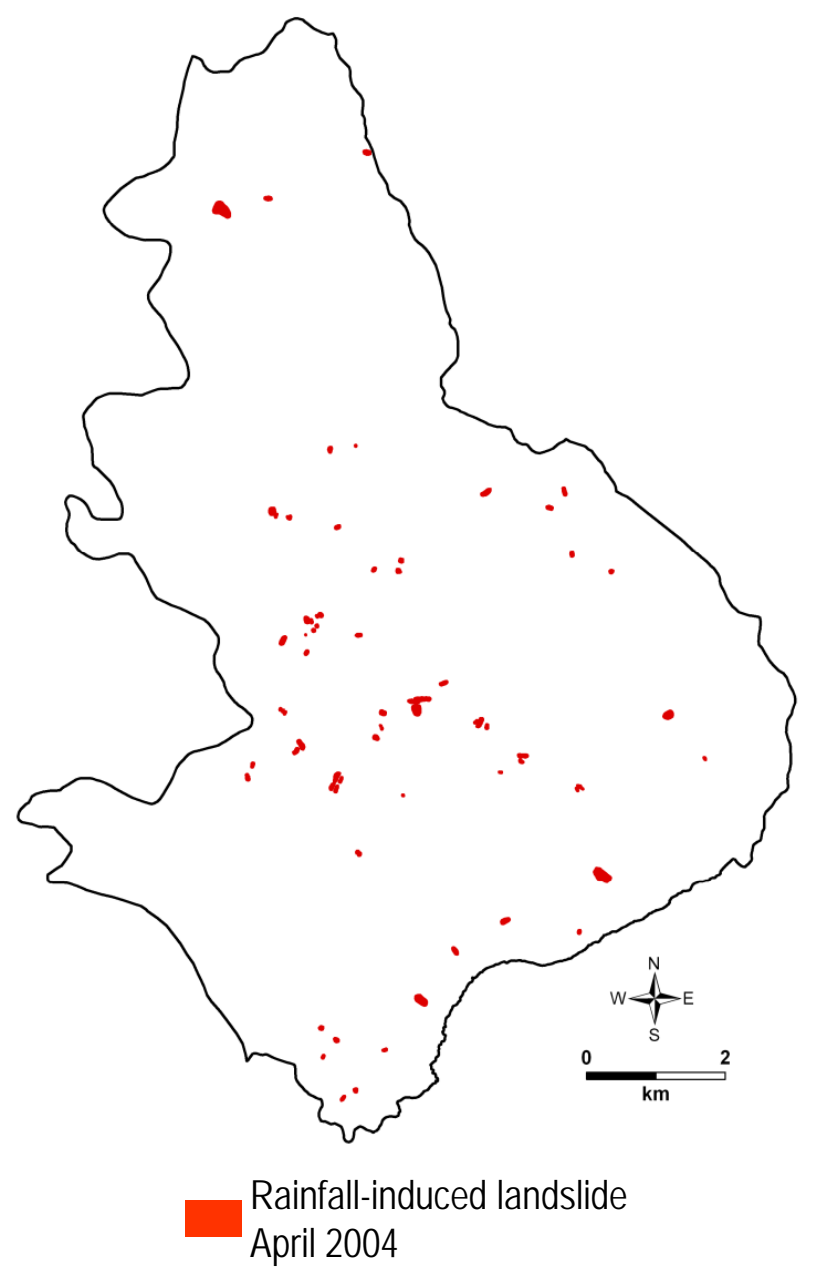

Fig. 4. Landslide event inventory map showing rainfall-induced landslides occurred in April 2004 in the the Collazzone area.

21.8 million elevation points were collected, for an average density of one point every $4.1 \mathrm{~m}^{2}$. ESRI ${ }^{\circledR}$ ArcGIS $^{\mathrm{TM}}$ version 8.3 was used to transform the cloud of irregularly spaced elevation points to a regular grid of elevation values spaced $2 \mathrm{~m} \times 2 \mathrm{~m}$ on the ground $\left(\mathrm{DEM}_{2}\right)$ (Fig. 7).

\section{Analysis and discussion}

The landslide and topographic information was used to perform three analyses in the Collazzone area. The first analysis consisted in establishing the extent to which the Lidar elevation data obtained by ALSM can be used to identify and map the recent rainfall-induced landslides. The second analysis consisted in comparing statistics of landslide area obtained from the reconnaissance field inventory and a revised (corrected) inventory obtained exploiting the Lidar elevation information. The third analysis was aimed at comparing the 

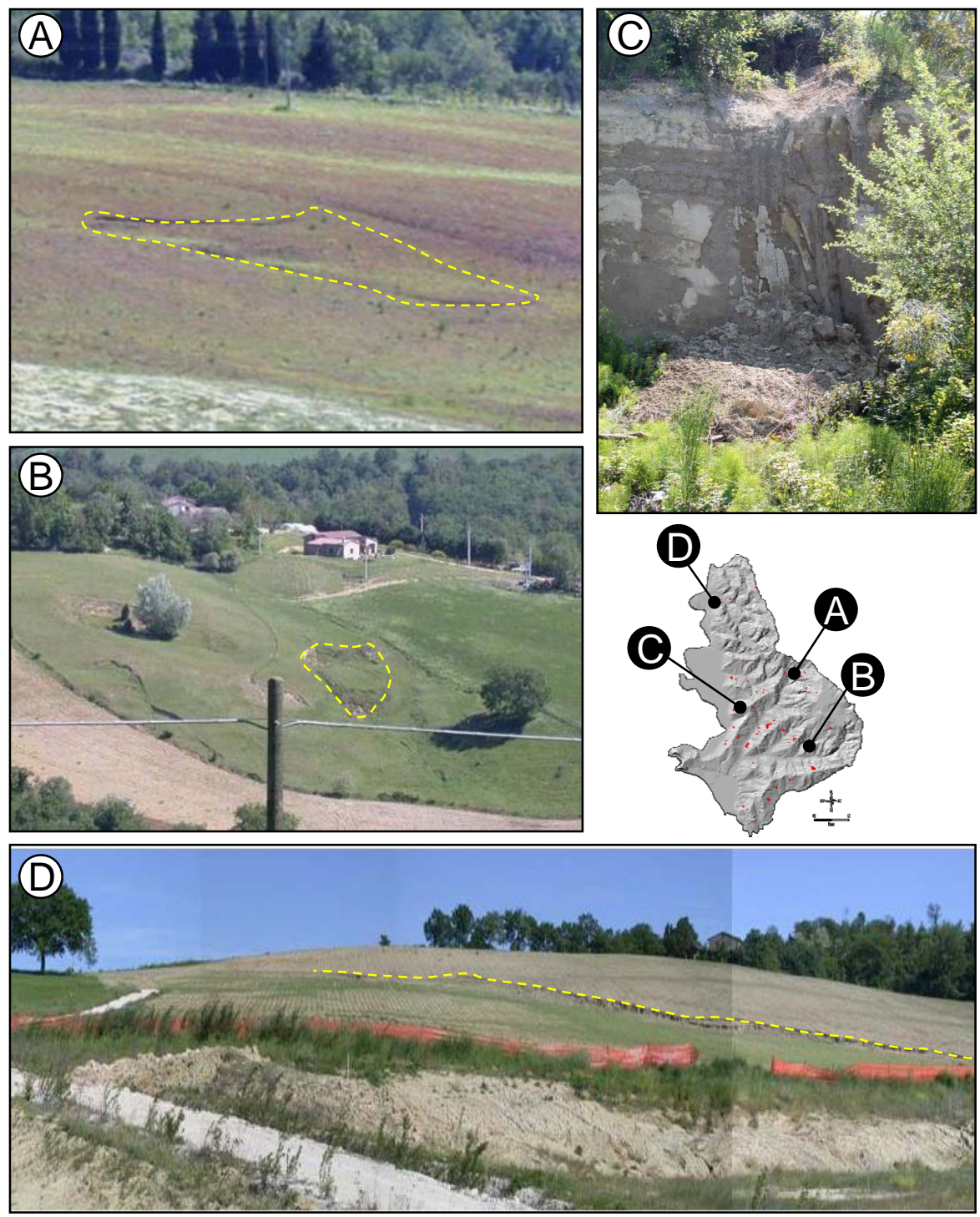

Fig. 5. Recent rainfall induced landslides mapped during a reconnaissance field survey conducted in April 2004 in the Collazzone area. Yellow dashed lines show landslide boundary. (A) Shallow soil slide. (B) Shallow compound slide - earth flow. (C) Shallow disrupted slide. (D) Crown area of deep-seated translational slide.

topographic signature (Pike, 1988) captured by the two available DEMs in landslide and in stable areas.

\subsection{Identification and mapping of recent rainfall induced landslides}

Recent rainfall-induced landslides in the Collazzone area left discernable morphological features on the topographic surface (Fig. 5). Recognition of these morphological features allowed geomorphologists to identify and map the new landslides during the reconnaissance field survey. We tested the possibility of using the high resolution $\mathrm{DEM}_{2}$ acquired by ALSM shortly after landslide occurrence, to identify, locate and map the recent slope failures. Since the effects of forest and ALSM side-laps were not removed from the Lidar elevation data, the test was performed in a reduced portion of the study area free of forest and not affected by side-lap effects. The reduced portion corresponds to 22 sub-areas (red boxes in Fig. 7) collectively covering $10.9 \mathrm{~km}^{2}$ ( $12.2 \%$ of the study area and $13.8 \%$ of the hilly portion of the study area), and encompassing representative topography and landslide types.

Derivate maps showing topography in the selected subareas were obtained from the high-resolution $\mathrm{DEM}_{2}$. For each sub-area, a shaded relief image, a slope map, and a contour map (one-meter interval) were prepared. The three derivative maps were inspected visually - singularly and in combination - for morphological features indicative of re- 
cent landslides. The result was a revised landslide event inventory map for the 22 selected sub-areas (Fig. 7). Figure 8 shows three examples of landslides mapped through visual inspection of the derivative maps obtained from $\mathrm{DEM}_{2}$.

Results of the test showed that Lidar elevation data are useful for the identification and mapping of the recent rainfallinduced landslides in the Collazzone area. More precisely:

(i) Deep-seated landslides exhibited morphological features visible in the shaded relief images and the slope maps (Fig. 8a-c). Field inspection of the deep-seated landslides revealed that the escarpments bounding the crown areas ranged from about $0.5 \mathrm{~m}$ to more than $3 \mathrm{~m}$, and that surface displacements caused by the landslides (e.g., fractured blocks, hummocks, pressure ridges, depressions, etc.) ranged in local relief from a few decimetres to more than $2 \mathrm{~m}$. In the shaded relief images, scarps and ground fractures in the landslide crown area, hummocky topography in the landslide deposit, and lobate forms at the landslide toe, were apparent (Fig. 8). The boundaries of the landslide deposit and of the crown area were also visible in the slope maps (Fig. 8).

(ii) Compound, mostly shallow slide - earth flows were characterized by morphological features less distinct than those typical of deep-seated landslides (Fig. 8df). In places, these morphological features (e.g., escarpments, cracks, hummocks, pressure ridges, etc.) were discernible in the shaded relief images and in the slope map, allowing for the identification and mapping of the rainfall-induced landslides. In other places, the morphological features of shallow slide - earth flows were not clearly visible in the derivative topographic maps. These features could not be attributed univocally to a landslide, making the identification and mapping of the rainfall-induced slope failures uncertain or impossible.

(iii) Shallow soil slides were small, and left faint morphological signs on the topographic surface (Fig. 8g-i). Field inspection of some of the mapped soil slides revealed that surface deformation in the crown area was less than $0.5 \mathrm{~m}$, and in places less than $0.2 \mathrm{~m}$. These features were generally not distinguishable in the shaded relief images and the slope maps (Fig. 8), and soil slides could not be mapped from the digital derivative topographic maps.

It should be noted that the same team of geomorphologists that performed the reconnaissance field mapping performed the visual analysis of the digital terrain derivative maps. When performing the visual analysis of the derivative maps, the interpreters were informed of the type, abundance, and approximate location of the rainfall-induced landslides. This has introduced a bias in the identification of the landslides. It remains undetermined the extent to which the recent rainfall-induced landslides in the Collazzone area - and

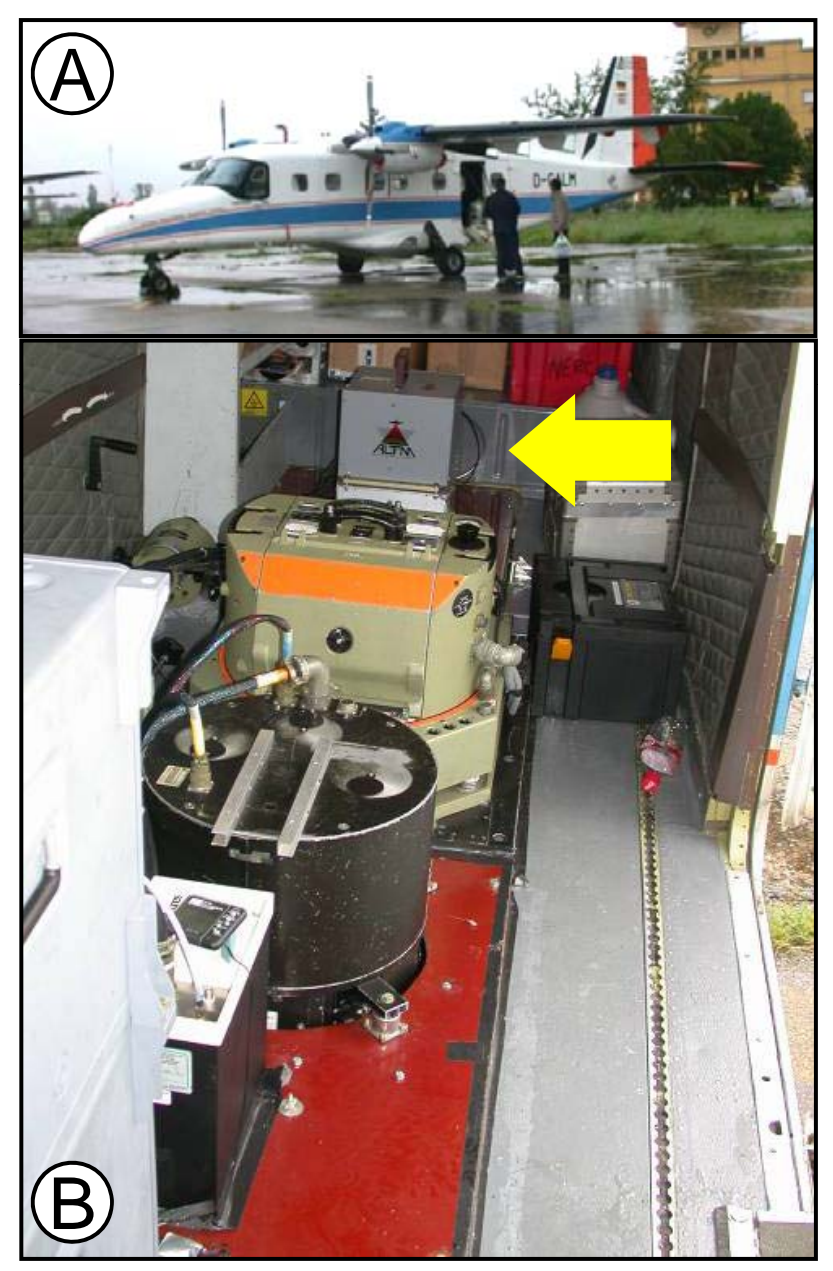

Fig. 6. (A) Dornier 228-110 aircraft operated by the Airborne Research and Survey Facility of the UK National Environment Research Council that flew the Optech's Airborne Laser Terrain Mapper 3033, shown by the arrow in $(\mathbf{B})$.

elsewhere in Umbria - could be identified and mapped accurately solely from the visual interpretation of the digital terrain maps, i.e., without previous information on the location and type of the slope failures.

\subsection{Comparison of the inventories}

The original landslide-event reconnaissance mapping and the revised landslide event mapping updated exploiting the Lidar elevation data were compared in the 22 sub-areas where both inventories are available (Fig. 7). Comparison was aimed at verifying differences in the number, size, and position of the mapped landslides.

In the 22 selected sub-areas, the original reconnaissance field inventory map shows 37 landslides, ranging in size from $165 \mathrm{~m}^{2}$ to $31910 \mathrm{~m}^{2}$, for a total landslide area of $193046 \mathrm{~m}^{2}$ (Table 1). In the same 22 sub-areas, the revised inventory map shows 47 landslides, ranging in size from $60 \mathrm{~m}^{2}$ to 


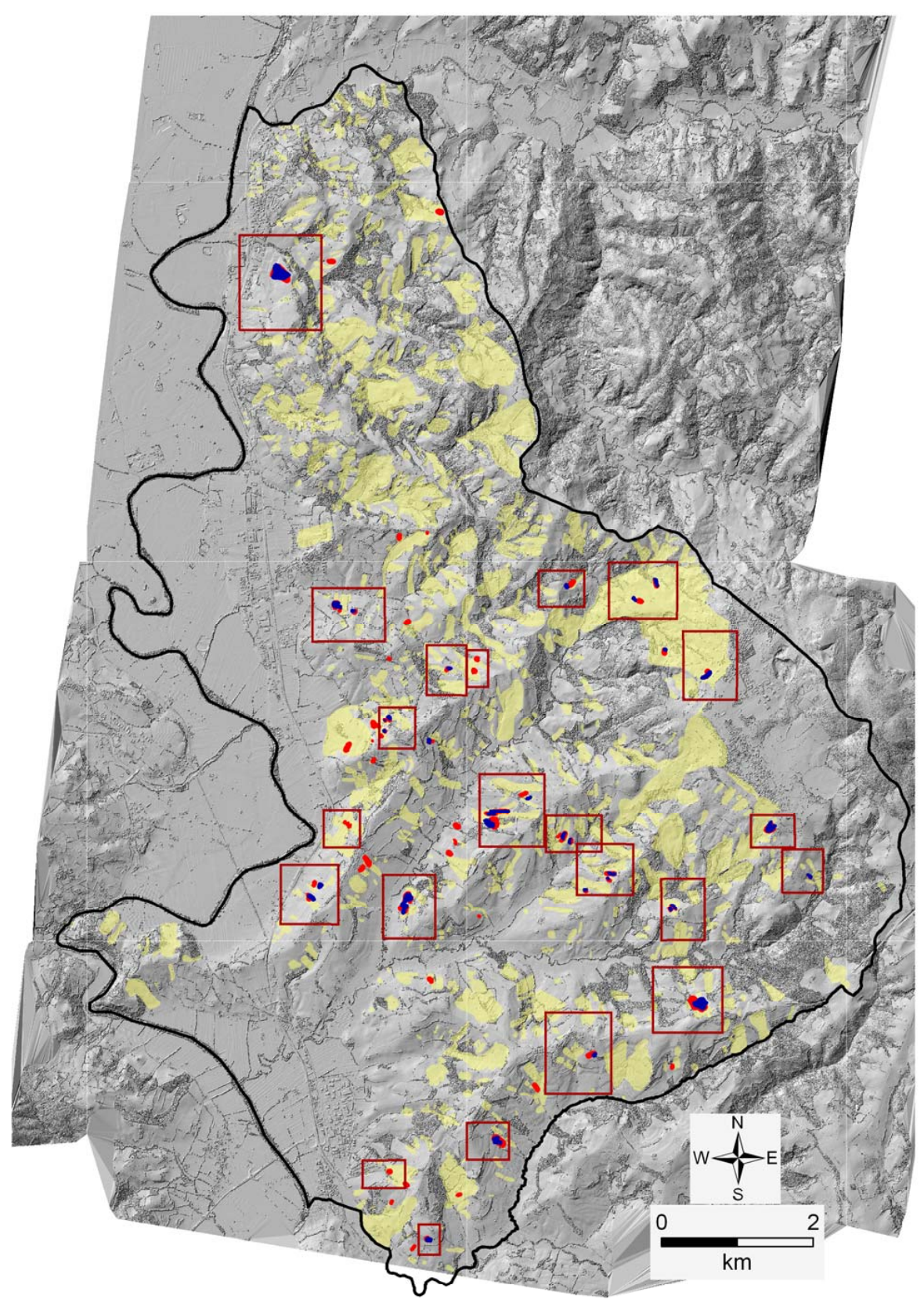

Fig. 7. Shaded relief image encompassing the Collazzone study area (shown by dark black line) prepared from a $2 \mathrm{~m} \times 2 \mathrm{~m}$ Digital Elevation Model $\left(\mathrm{DEM}_{2}\right)$ obtained interpolating 55.7 million elevation data collected by an Airborne Laser Scanner on 3 May 2004. Light yellow polygons are pre-existing landslides shown in the multi-temporal inventory (Fig. 3). Red polygons show recent rainfall-induced landslides mapped through reconnaissance field survey in April 2004 (Fig. 4). Blue polygons show revised inventory prepared exploiting derivative topographic maps obtained from $\mathrm{DEM}_{2}$. Red boxes indicate 22 sub-areas selected for a comparison of the inventories.

$25900 \mathrm{~m}^{2}$, for a total landslide area of $118439 \mathrm{~m}^{2}$. The revised inventory map shows $27 \%$ more landslides and $39 \%$ less total landslide area. This corresponds to a smaller average $\left(2520 \mathrm{~m}^{2}\right.$ vs. $\left.5219 \mathrm{~m}^{2}\right)$ and median $\left(1128 \mathrm{~m}^{2}\right.$ vs. $2812 \mathrm{~m}^{2}$ ) landslide sizes (Table 1).

Statistics of landslide areas for the two inventory maps are summarised in Fig. 9, for all the mapped landslides, and for the deep-seated and the shallow landslides. Inspection of the box plots reveals that the revised inventory map shows smaller landslides, for all landslide types. The area of the individual landslides mapped during the original reconnaissance field survey was larger than the area of the same landslides mapped using the Lidar elevation data. Reasons for the differences are manifold, including: (i) perspective, lo- 


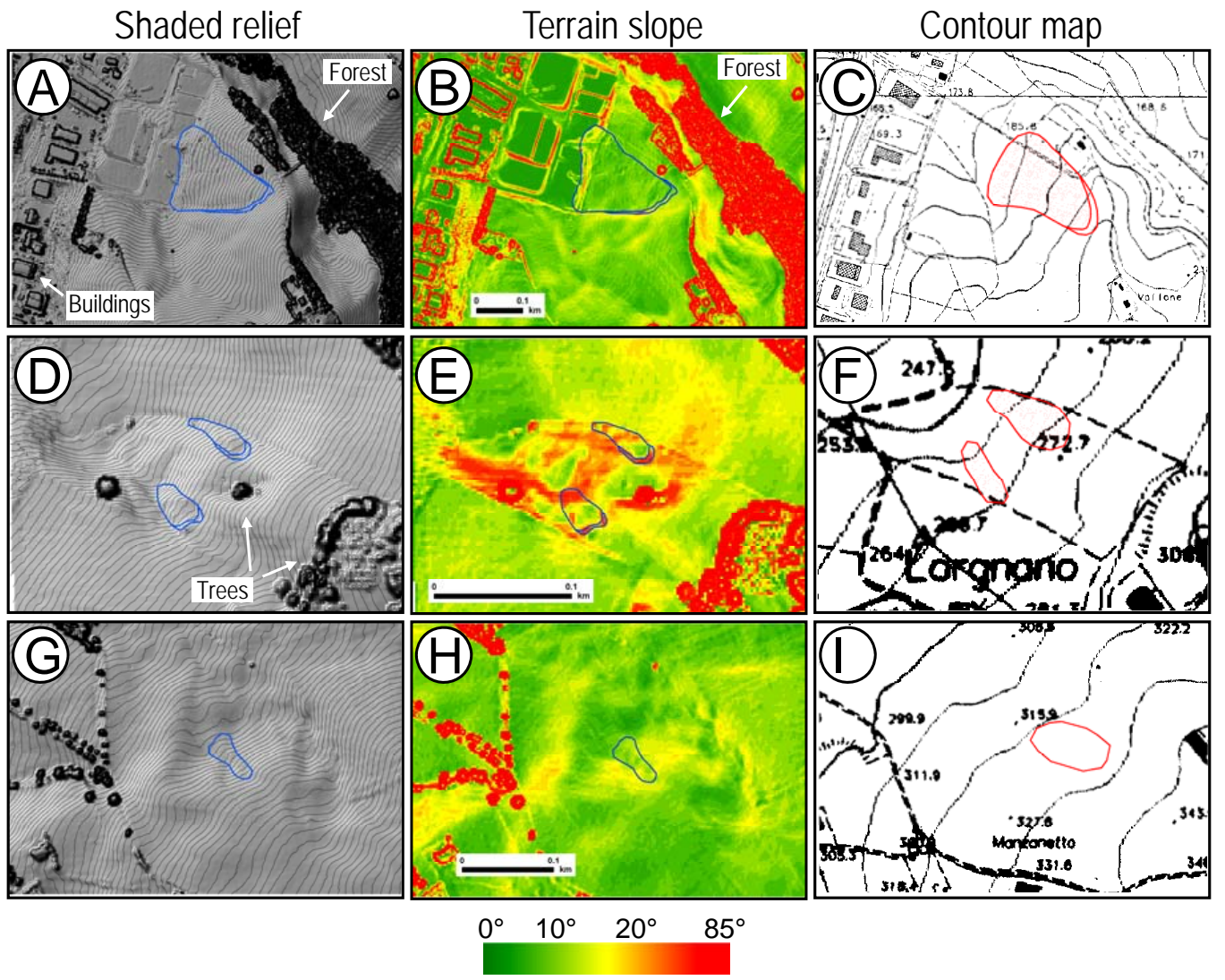

Fig. 8. Examples of recent rainfall-induced landslides mapped in the Collazzone area. Red lines show landslides identified and mapped during the reconnaissance field surveys. Blue lines show landslides identified and mapped using derivative topographic maps obtained from $\mathrm{DEM}_{2}$. Shaded relief images show 1-m contour lines obtained from $\mathrm{DEM}_{2}$. Contour maps portray 10- and 5-m contour lines and other topographic features shown in the CTR base maps. (A), (B), (C) deep-seated translational slide. (D), (E), (F) compound slide - earth flows. (G), (H), (I) shallow soil slide.

cally incomplete or inaccurate, view of the landslide in the field, (ii) poor or incorrect representation of the topographic surface in the base map used to map landslides in the field, and (iii) limited time available to the geomorphologists to map the individual landslides in the field.

Visual comparison of the two inventories in the 22 selected sub-areas indicates that the revised inventory map shows landslide boundaries with an improved cartographic detail. In the adjusted inventory map, individual landslides match more accurately the representation of topography provided by the one meter contour lines, than the same landslides shown in the field inventory and mapped on the CTR topographic base maps. The CTR maps show a topography that predates the new landslides, making it difficult for the geomorphologists to map the landslides accurately, particularly small landslides in cultivated fields or grassland areas. The Lidar elevation data were acquired shortly after the occurrence of the rainfall-induced landslides, and captured the changed (altered) morphology. This facilitated the accurate mapping of the recent landslides.
Table 1. Collazzone study area, central Umbria. Characteristics of landslide event inventory maps for 22 selected sub-areas. (A) Original reconnaissance inventory map obtained through field surveys. (B) Revised inventory map prepared exploiting derivative maps obtained from $\mathrm{DEM}_{2}$.

\begin{tabular}{lccc}
\hline & & A & B \\
\hline Number of mapped landslides & $\#$ & 37 & 47 \\
Total landslide area & $\mathrm{m}^{2}$ & 193046 & 118439 \\
Minimum landslide area & $\mathrm{m}^{2}$ & 165 & 60 \\
Maximum landslide area & $\mathrm{m}^{2}$ & 31910 & 25900 \\
Mean landslide area & $\mathrm{m}^{2}$ & 5219 & 2520 \\
Median landslide area & $\mathrm{m}^{2}$ & 2812 & 1128 \\
Standard deviation of landslide area & $\mathrm{m}^{2}$ & 6835 & 4450 \\
\hline
\end{tabular}

Figure 10 summarizes typical mismatches between landslides shown in the original reconnaissance inventory (shown in red) and landslides portrayed in the revised inventory 


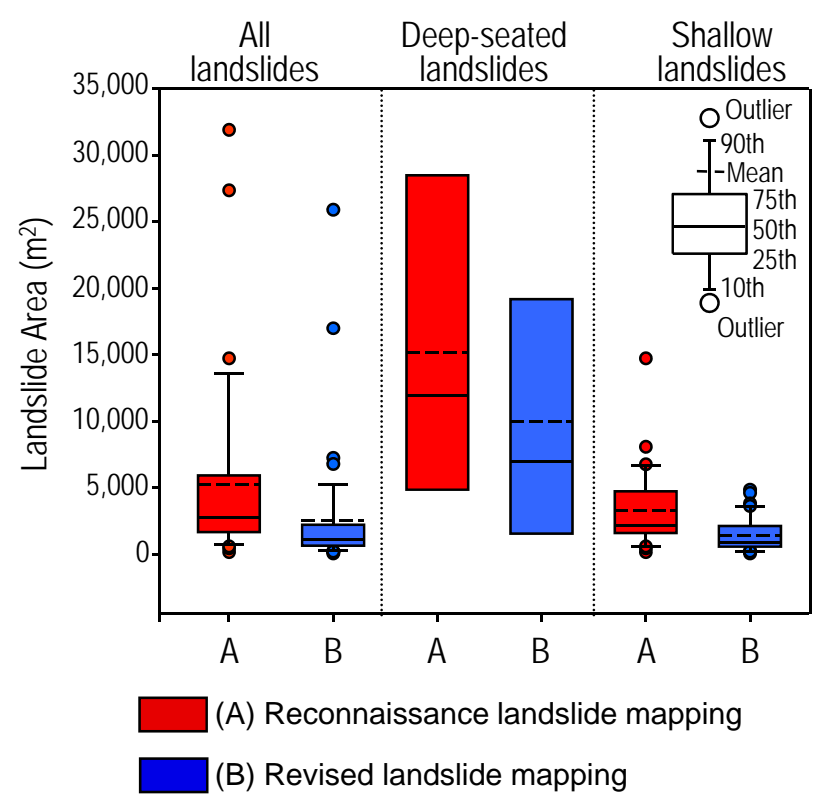

Fig. 9. Comparison of the statistics of landslide area obtained from the original reconnaissance inventory map (red) and the inventory revised using derivative maps obtained from the Lidar elevation data (blue) in 22 selected sub-areas (see Fig. 7). Box plots are shown for all landslides, for deep-seated landslides, and for shallow landslides.

(shown in blue). Some of the landslides were mapped in a slightly different geographical location (Fig. 10a). Other landslides were mapped in the same geographical location but the extent of the landslide was larger (overestimated) in the reconnaissance inventory (Fig. 10b). In places, a single (larger) landslide was mapped in the reconnaissance inventory, where the same morphological features were attributed to multiple (smaller) landslides in the revised inventory map (Fig. 10c).

To quantify the geographical mismatch between the two inventory maps, the method proposed by Carrara et al. (1992) was adopted. For the purpose, the overall mapping error index, $E$, was computed

$E=\frac{(A \cup B)-(A \cap B)}{(A \cup B)}, \quad 0 \leq E \leq 1$

where $A$ and $B$ are the total landslide area in the first (original) and in the second (revised) inventory map, respectively, and $U$ and $\cap$ are the geographical union and intersection of the two inventory maps. From Eq. (1), the degree of matching, $M$, between two inventory maps (Galli et al., 2007) is

$M=1-E, \quad 0 \leq M \leq 1$

If two inventory maps show exactly the same landslides in the same positions (a rather improbable situation) matching is perfect $(M=1)$ and mapping error is null $(E=0)$. If two landslide maps are completely different, cartographic matching is null $(M=0)$ and mapping error is maximum $(E=1)$ (Galli et al., 2007).

Geographical union $(\cup)$ and intersection $(\cap)$ of the original and the revised inventory maps was performed in a GIS. The obtained figures were used to compute the mapping error index $(E)$ and the cartographic matching index $(M)$. Geographical union of the two inventory maps was $2.36 \times 10^{5} \mathrm{~m}^{2}$, and landslide area common to both inventory maps was $7.50 \times 10^{4} \mathrm{~m}^{2}$ (Fig. 10). From Eq. (1) and Eq. (2), the map error index $E$ was 0.68 and the map match index $M$ was 0.32 . These figures indicate a significant discrepancy between the two inventories (Galli et al., 2007). We attribute the large geographical mismatch to mapping errors in the original field inventory. Inspection of the largest discrepancies revealed that most of the errors were due primarily to: (i) the locally poor quality of the base maps used to map the landslides in the field, and (ii) the lack of a complete (vertical) view of the landslides in the field.

\subsection{Comparison of Digital Elevation Models}

The last test consisted in evaluating how well $\mathrm{DEM}_{2}$ and $\mathrm{DEM}_{10}$ captured the topographic signature of landslide terrain (Pike, 1988). For the purpose, three slopes with different landslide abundance and failures of different ages were selected, including (Fig. 11): (i) a slope free of known landslides, (ii) a slope where recent (April 2004) and preexisting (1941-1997) landslides were identified, and (iii) a slope where only pre-existing (1941-1997) landslides were known.

Maps of the local terrain gradient were prepared for the three selected slopes, and their descriptive statistics compared. Results, summarized in Fig. 12, reveal that the higher resolution $\mathrm{DEM}_{2}$ captured a more diversified topography than the coarser resolution $\mathrm{DEM}_{10}$. The consistently larger range of terrain gradient shown by $\mathrm{DEM}_{2}$ reveals this, although the average and the median values of terrain gradient are about the same for the two DEMs (Fig. 12). DEM 2 shows steeper or much steeper terrain and a considerably larger proportion of steep terrain, for all the considered slopes.

Joint inspection of Figs. 11 and 12 allows for additional considerations on how well the two DEMs captured - or did not capture - the topographic signature of landslides. Differences in the statistics of terrain gradient are largest where recent (April 2004) and pre-existing (1941-1997) landslides were recognized (slope \#2 in Fig. 11), are significant where only pre-existing (1941-1997) landslides were mapped (slope \#3 in Fig. 11), and are smallest in the slope free of known landslides (slope \#1 in Fig. 11). The differences suggest that the two DEMs captured landslide morphology differently.

Immediately after a landslide event, individual landslides are "fresh" and usually clearly recognizable (Malamud et al., 2004). Landslide morphology becomes increasingly indis- 


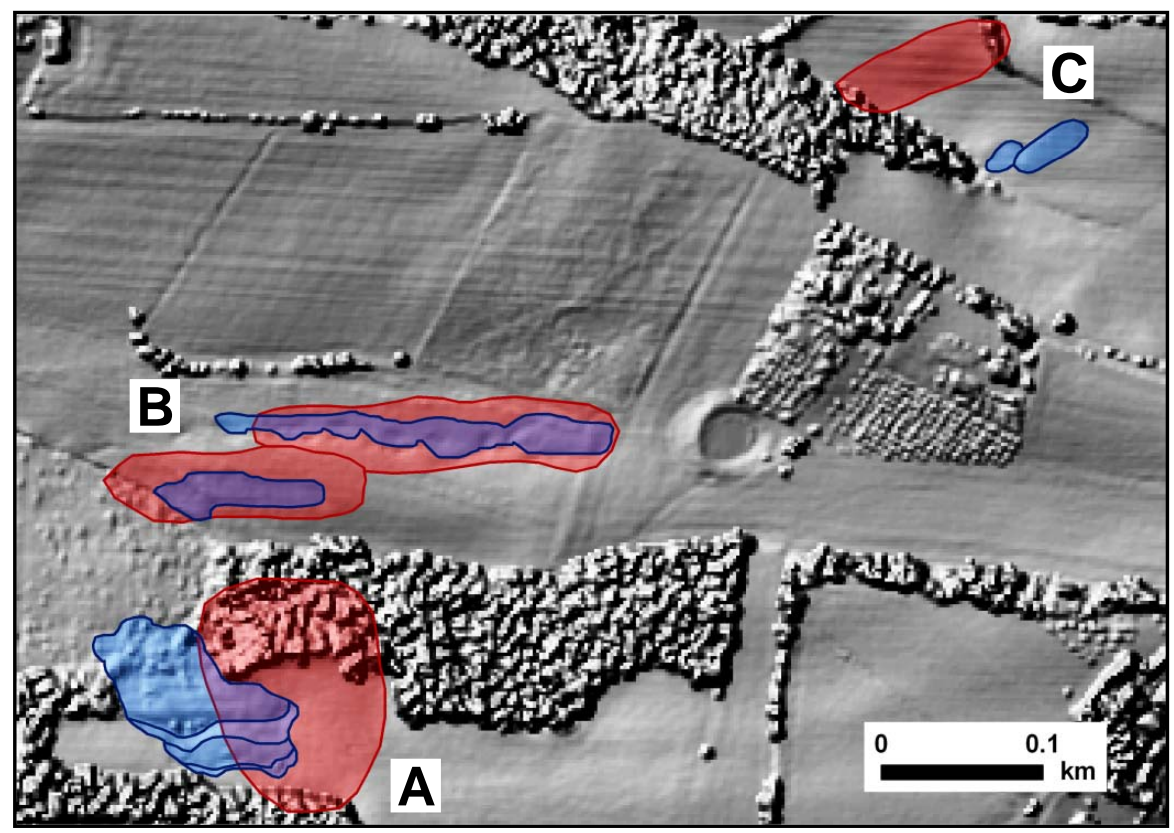

Fig. 10. Typical differences between landslides shown in the original reconnaissance inventory map (shown in red), and landslides shown in the revised inventory map prepared exploiting derivative topographic maps obtained from $\mathrm{DEM}_{2}$ (shown in blue).

tinct with the age of the landslide (McCalpin, 1984). This is caused by various factors, including local adjustments of a landslide to the new morphological setting, new landslides, erosion, land use changes, and human actions (e.g., ploughing). In the Collazzone area, distinct morphological features (e.g., scarps, ridges, hummocks, cracks, sinks, etc.) characterize the recent rainfall-induced landslides. These features contribute to "fresh" landslide morphology, well captured by $\mathrm{DEM}_{2}$ but inadequately shown by the lower resolution $\mathrm{DEM}_{10}$ (slope \#2 in Fig. 11). In the study area, old (pre-existing and 1941-1997) landslides exhibit a typical "smoothed" morphology, characterized by curved hummocks, poorly distinct rounded escarpments, and gentle slopes. This morphology is well captured by $\mathrm{DEM}_{2}$ and is partially captured by $\mathrm{DEM}_{10}$ (slope \#3 in Fig. 11). Where no landslides have occurred (slope \#1 in Fig. 11), slopes are regular and their morphology controlled by lithology and the attitude of bedding planes. The morphology of stable slopes is (almost) equally well captured by $\mathrm{DEM}_{2}$ and $\mathrm{DEM}_{10}$. We conclude that the improved topographic information provided by $\mathrm{DEM}_{2}$ is significant where recent rainfall-induced landslides have occurred, and is much less significant in improving the representation of stable (landslide free) slopes.

\section{Conclusions}

Landslide inventory maps are important sources of information for landslide susceptibility, hazard and risk assessment (Guzzetti et al., 2000; Galli et al., 2007). Landslide event inventory maps are particularly significant because - if properly prepared - they are nearly complete, i.e., they show all the landslides produced by an individual landslide trigger (e.g., a rainstorm, an earthquake, a rapid snowmelt event). Preparing a complete landslide event inventory map is difficult, and geomorphologists have experimented with methods to reduce the time and costs for the production of landslide event inventories. In this work, we have reported on an experiment aimed at exploiting high-resolution elevation data obtained by an airborne laser scanner (ALS) to map recent rainfall-induced landslides in Umbria, central Italy.

For the Collazzone area, digital elevation data were obtained by Airborne Lidar Swath Mapping on 3 May 2004, shortly after a prolonged period of rainfall that resulted in numerous landslides in the study area. Field surveys conducted immediately after the rainfall period allowed mapping 70 landslides in the Collazzone area, for a total landslide area of $2.7 \times 10^{5} \mathrm{~m}^{2}$. Successively, the Lidar elevation data were interpolated to obtain a $2 \mathrm{~m} \times 2 \mathrm{~m}$ Digital Elevation Model $\left(\mathrm{DEM}_{2}\right)$. The high-resolution $\mathrm{DEM}_{2}$ was used to assess whether the Lidar elevation data could be exploited to map the recent rainfall-induced landslides. Shaded relief images and slope maps obtained from $\mathrm{DEM}_{2}$ for 22 selected subareas were used to update the reconnaissance landslide inventory. Inspection of the revised inventory revealed that landslides mapped exploiting the Lidar elevation data matched topography more accurately than the same landslides mapped using the pre-existing topographic maps. In the 22 selected sub-areas, the revised inventory showed $27 \%$ more landslides 

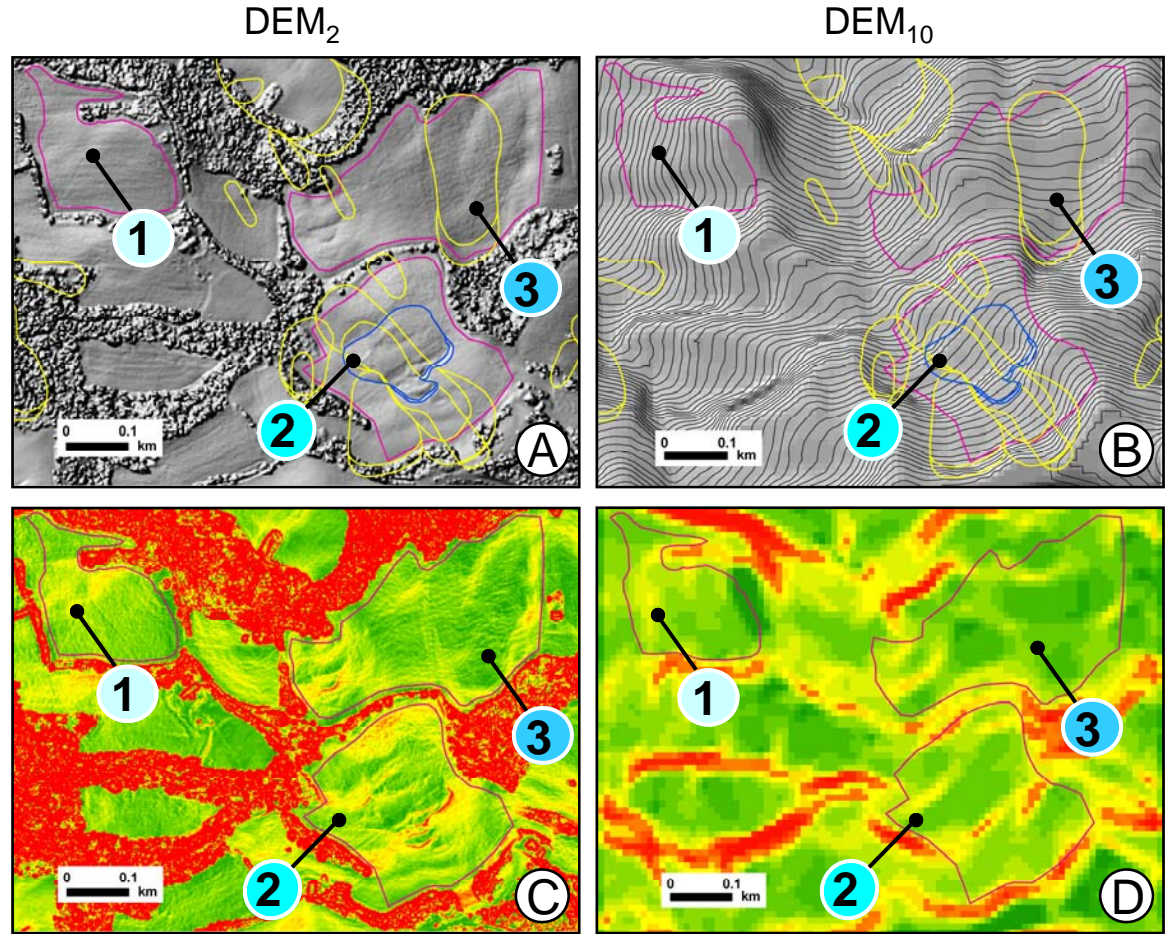

$0^{\circ} \quad 10^{\circ}$

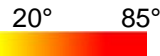

Fig. 11. Comparison of two DEMs in stable and in landslide areas. (A) Shaded relief obtained from DEM 2 . (B) Shaded relief derived from $\mathrm{DEM}_{10}, 1-\mathrm{m}$ contour lines are shown. (C) Map of terrain gradient (slope) obtained from DEM 2 . (D) Map of terrain gradient (slope) obtained from $\mathrm{DEM}_{10}$. Yellow lines show pre-existing landslides, and blue lines show recent (April 2004) rainfall-induced landslides. Purple lines show selected slopes. Coloured numbers indicate: (1) a slope free of known landslides, (2) a slope with recent (April 2004) and pre-existing (1941-1997) known landslides, and (3) a slope with only pre-existing (1941-1997) known landslides.

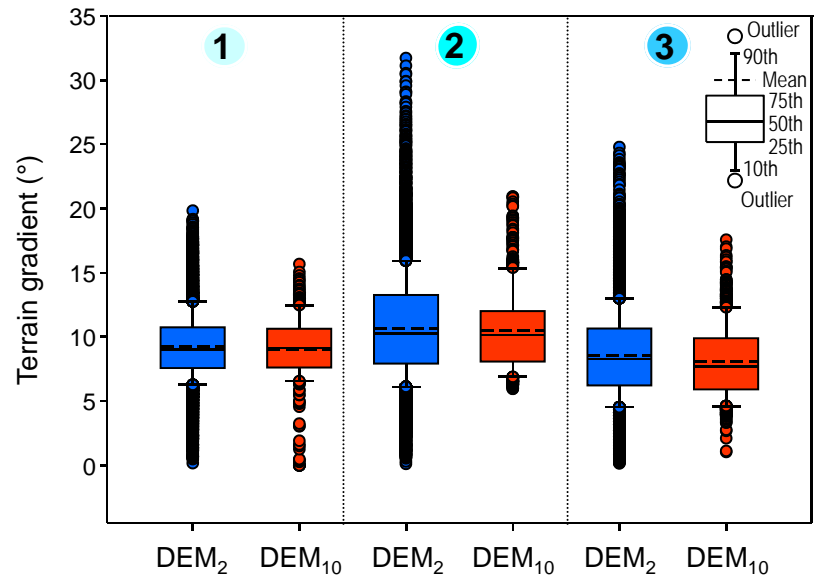

Fig. 12. Comparison of terrain gradient statistics obtained from $\mathrm{DEM}_{2}$ and $\mathrm{DEM}_{10}$ in three selected slopes (see Fig. 11). (1) Slope free of known landslides, (2) slope with recent (April 2004) and pre-existing (1941-1997) known landslides, (3) slope with only preexisting (1941-1997) known landslides. and 39\% less landslide area, corresponding to a smaller average landslide size. This is important information for geomorphologists interested in the statistics of landslide areas (e.g., Malamud et al., 2004), and has implications for the assessment of landslide hazard (Guzzetti et al., 2006a) and for the validation of landslide hazard forecasts (Guzzetti et al., 2006b). Since the geomorphologists that performed the visual analysis of the derivative topographic maps were informed of the presence of the rainfall-induced landslides, it remains undetermined the extent to which the recent landslides in the Collazzone area could be mapped accurately solely from the visual interpretation of the digital terrain maps.

Further analysis of the discrepancy between the original reconnaissance inventory map and the revised inventory revealed locally significant differences that were attributed to mapping errors and imprecision mostly in the reconnaissance field inventory. The errors and the imprecision were attributed chiefly to: (i) the incomplete or inaccurate view of some the landslides in the field, (ii) the locally imprecise representation of the topographic surface in the base maps used to map the landslides, and (iii) the limited time available to map the new landslides in the field. 
Finally, the high resolution $\mathrm{DEM}_{2}$ was compared to the pre-existing, coarser resolution $(10 \mathrm{~m} \times 10 \mathrm{~m}), \mathrm{DEM}_{10}$ to establish how well the two digital representations of topography captured the topographic signature of landslides. Results indicate that the higher resolution $\mathrm{DEM}_{2}$ was capable of capturing a more diversified topography than the coarser resolution $\mathrm{DEM}_{10}$. Differences in the statistics of terrain gradient obtained from the two DEMs were largest where recent and pre-existing landslides were present, intermediate where only pre-existing landslides were present, and reduced in areas free of known landslides. The finding has implications for the recognition and mapping of landslides, and may lead to the automatic or semi-automatic extraction of landslide features from high resolution DEMs obtained from Lidar elevation data.

Acknowledgements. We are grateful to M. Jaboyedoff and to a second anonymous referee for their constructive comments. We express gratitude to N. Hovius for making the Lidar survey possible, and C. P. Stark for field assistance. The Airborne Remote Sensing Facility of the U.K. National Environmental Research Council flew the Laser Terrain Mapper. The Unit of Landscape Modelling of Cambridge University processed the Lidar data. Work partly financed by CNR - IRPI, CNR - GNDCI, and ASI MORFEO grants.

Edited by: T. Glade

Reviewed by: M. Jaboyedoff and another anonymous referee

\section{References}

Ackermann, F.: Airborne Laser Scanning - Present status and future expectations, ISPR Journal of Photogrammetry \& Remote Sensing, 54, 64-67, 1999.

Barchi, M., Brozzetti, F., and Lavecchia, G.: Analisi strutturale e geometrica dei bacini della media valle del Tevere e della valle umbra. Bollettino Società Geologica Italiana, 110, 65-76 (in Italian), 1991.

Brunsden, D.: Landslide types, mechanisms, recognition, identification, in: Landslides in the South Wales coalfield, edited by: Morgan, C. S., Proceedings Symposium, April 1-3, The Polytechnic of Wales, 19-28, 1985.

Brunsden, D.: Mass movements; the research frontier and beyond: a geomorphological approach, Geomorphology, 7, 85-128, 1993.

Bucknam, R. C., Coe, J. A., Chavarria, M. M., Godt, J. W., Tarr, A. C., Bradley, L.-A., Rafferty, S., Hancock, D., Dart, R. L., and Johnson, M. L.: Landslides Triggered by Hurricane Mitch in Guatemala - Inventory and Discussion, U.S. Geological Survey Open File Report 01-443, 2001.

Cardinali, M., Ardizzone, F., Galli, M., Guzzetti, F., and Reichenbach, P.: Landslides triggered by rapid snow melting: the December 1996-January 1997 event in Central Italy, in: Proceedings 1st EGS Plinius Conference, edited by: Claps, P. and Siccardi, F., Maratea, Bios Publisher, Cosenza, 439-448, 2001.

Cardinali, M., Galli, M., Guzzetti, F., Ardizzone, F., Reichenbach, P., and Bartoccini, P.: Rainfall induced landslides in December 2004 in South-Western Umbria, Central Italy, Nat. Hazards Earth
Syst. Sci., 6, 237-260, 2006,

http://www.nat-hazards-earth-syst-sci.net/6/237/2006/.

Carrara, M. Cardinali, M., and Guzzetti, F.: Uncertainty in assessing landslide hazard and risk, ITC Journal, 2, 172-183, 1992.

Catani, F., Farina, P., Moretti, S., Nico, G., and Strozzi, T. On the application of SAR interferometry to geomorphological studies: estimation of landform attributes and mass movements, Geomorphology, 66, 1-4, 119-131, 2005.

Cencetti, C. Il Villafranchiano della "riva umbra" del F. Tevere: elementi di geomorfologia e di neotettonica, Bollettino Società Geologica Italiana, 109, 2, 337-350 (in Italian), 1990.

CENR/IWGEO: Strategic Plan for the U.S. Integrated Earth Observation System. National Science and Technology Council Committee on Environment and Natural Resources, Washington, D.C., available at http://iwgeo.ssc.nasa.gov, 2005.

Cheng, K. S., Wei, C., and Chang, S. C.: Locating landslides using multi-temporal satellite images, Adv. Space Res., 33, 3, 96-301, 2004.

Conti, M. A. and Girotti, O.: Il Villafranchiano nel "Lago Tiberino", ramo sud-occidentale: schema stratigrafico e tettonico, Geologia Romana, 16, 67-80 (in Italian), 1977.

Czuchlewski, K. R., Weissel, J. K., and Kim, Y.: Polarimetric synthetic aperture radar study of the Tsaoling landslide generated by the 1999 Chi-Chi earthquake, Taiwan, J. Geophys. Res., 108(F1), 7/1-10, 6006, doi:10.1029/2003JF000037, 2003.

Franklin, A. J.: Slope instrumentation and monitoring, in: Slope Instability, edited by: Brunsden, D. and Prior, D. B., John Wiley and Sons, 1-25, 1984.

Galli, M., Ardizzone, F., Cardinali, M., Guzzetti, F., and Reichenbach, P.: Comparison of landslide inventory maps, Geomorphology, in press, 2007.

Guzzetti, F., Cardinali, M., Reichenbach, P., and Carrara, A.: Comparing landslide maps: A case study in the upper Tiber River Basin, central Italy, Environ. Manage., 25, 3, 247-363, 2000.

Guzzetti, F., Cardinali, M., Reichenbach, P., Cipolla, F., Sebastiani, C., Galli, M., and Salvati, P.: Landslides triggered by the 23 November 2000 rainfall event in the Imperia Province, Western Liguria, Italy, Eng. Geol., 73, 2, 229-245, 2004.

Guzzetti, F., Galli, M., Reichenbach, P., Ardizzone F., and Cardinali, M.: Landslide hazard assessment in the Collazzone area, Umbria, central Italy, Nat. Hazards Earth Syst. Sci., 6, 115-131, 2006a.

Guzzetti, F., Malamud, B. D., Turcotte, D. L., and Reichenbach, P.: Power-law correlations of landslide areas in Central Italy, Earth Planet. Sci. Lett., 195, 169-183, 2002.

Guzzetti, F., Reichenbach, P., Ardizzone, F., Cardinali, M., and Galli, M.: Estimating the quality of landslide susceptibility models, Geomorphology, 81, 166-184, 2006 b.

Hansen, A.: Landslide hazard analysis, in: Slope instability, edited by: Brunsden, D. and Prior, D. B., Wiley \& Sons, New York, 523-602, 1984.

Harp, E. L. and Jibson, R. L.: Landslides triggered by the 1994 Northridge, California earthquake, Seismological Society of America Bulletin, 86, S319-S332, 1996.

Hilley, G. E., Bürgmann, R., Ferretti, A., Novali, F., and Rocca, F.: Dynamics of Slow-Moving Landslides from Permanent Scatterer Analysis, Science, 304, 1952-1955, 2004.

IGOS Geohazards: IGOS Geohazards Theme Report, April 2003, European Space Agency, Data User Programme, http://dup.esrin. 
esa.it/igos-geohazards, 2003.

Kääb, A.: Monitoring high-mountain terrain deformation from repeated air- and spaceborne optical data: examples using digital aerial imagery and ASTER data ISPRS, Journal of Photogrammetry and Remote Sensing, 57, 1-2, 39-52, 2002.

Kovalev, V. A. and Eichinger, W. E.: Elastic Lidar: Theory, Practice, and Analysis Methods, Resources for John Wiley \& Sons INC., 615 pp., 2004.

Lillesand, T. M., Kiefer, R. W., and Chipman J. W.: Remote sensing and image interpretation, J. Wiley \& Sons, United States of America, 5th edition, 763 pp., 2004.

Malamud, B. D., Turcotte, D. L., Guzzetti, F., and Reichenbach, P.: Landslide inventories and their statistical properties, Earth Surf. Proc. Land., 29, 6, 687-711, 2004.

Mantovani, F., Soeters, R., and van Westen, C. J.: Remote sensing techniques for landslide studies and hazard zonation in Europe, Geomorphology, 15, 213-225, 1996.

McCalpin, J.: Preliminary age classification of landslides for inventory mapping, Proceedings 21st annual Engineering Geology and Soils Engineering Symposium, Moscow, Idaho, 99-111, 1984.

McKean, J. and Roering, J.: Objective landslide detection and surface morphology mapping using high-resolution airborne laser altimetry, Geomorphology, 57, 3-4, 331-351, 2003.

Pašek, J.: Landslide inventory, International Association Engineering Geologist Bulletin, 12, 73-74, 1975.

Petley, D. J.: Ground investigation, sampling and testing for studies of slope instability, in: Slope instability, edited by: Brunsden, D. and Prior, D. B., Wiley, Chichester, 67-101, 1984.

Pike, R. J.: The geometric signature: quantifying landslide-terrain types from digital elevation models, Math. Geol., 20, 5, 491-511, 1988.

Reichenbach, P., Guzzetti, F., and Cardinali, M.: Map of sites historically affected by landslides and floods in Italy, 2nd edition, CNR Gruppo Nazionale per la Difesa dalle Catastrofi Idrogeologiche Publication n. 1786, scale 1:1 $200000,1998$.

Rib, H. T. and Liang, T.: Recognition and identification, in: Landslide Analysis and Control, edited by: Schuster, R. L. and Krizek, R. J., National Academy of Sciences, Transportation Research Board Special Report 176, Washington, 34-80, 1978.
Salvati, P., Bianchi, C., and Guzzetti, F.: Catalogo delle Frane e delle Inondazioni Storiche in Umbria, CNR IRPI e Fondazione Cassa di Risparmio di Perugia, ISBN-10 88-95172-00-0, 278 pp., 2006.

Salvati, P., Guzzetti, F., Reichenbach, P., Cardinali, M., and Stark, C. P.: Map of landslides and floods with human consequences in Italy, CNR Gruppo Nazionale per la Difesa dalle Catastrofi Idrogeologiche Publication n. 2822, scale 1:1200 000, 2003.

Schulz, W. H.: Landslides mapped using LIDAR imagery, Seattle, Washington, United States Geological Survey Open File Report 2004-1396, 2004.

Schulz, W. H.: Landslides Susceptibility Estimated From Mapping Using Light Detection and Ranging (LIDAR) Imagery and Historical Landslide Records, Seattle, Washington, United States Geological Survey Open File Report 2005-1405, 2005.

Servizio Geologico Nazionale: Carta Geologica dell’Umbria, Map at 1:250000 scale (legend in Italian), 1980.

Singhroy, V.: Remote sensing of landslides, in: Landslide risk assessment, edited by: Glade, T., Anderson, M. G., and Crozier, M. J., John Wiley, 469-492, 2005.

Singhroy, V. and Molch, K.: Characterizing and monitoring rockslides from SAR techniques, Adv. Space Res., 33, 3, 290-295, 2004.

Turner, A. K. and Schuster, R. L. (Eds.): Landslides: Investigation and Mitigation, Washington, D.C., National Research Council, Transportation Research Board Special Report 247, 673 pp., 1996.

Wieczorek, G. F.: Preparing a detailed landslide-inventory map for hazard evaluation and reduction, Bulletin Association Engineering Geologists, 21, 3, 337-342, 1984.

Zinck, J. A., López, J., Metternicht, G. I., Shrestha, D. P., and Vázquez-Selem, L.: Mapping and modelling mass movements and gullies in mountainous areas using remote sensing and GIS techniques, Int. J. Appl. Earth Obs., 3, 1, 43-53, 2001. 